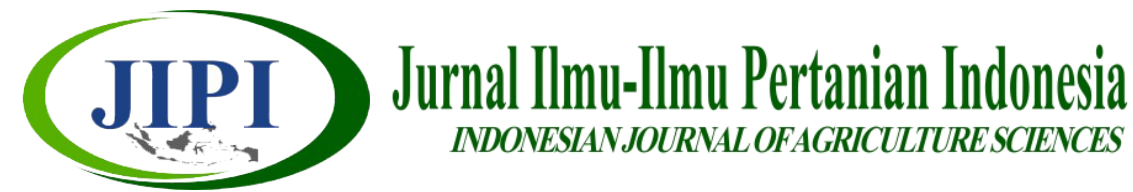

\title{
ANALISIS KORELASI DAN JALUR DALAM PENENTUAN KRITERIA SELEKSI UBI JALAR (Ipomoea batatas (L.) Lam.) BERDAYA HASIL TINGGI
}

\author{
Reza Prakoso Dwi Julianto ${ }^{1 *}$, Sri Umi Lestari ${ }^{1}$, Edyson Indawan ${ }^{1}$ \\ ${ }^{1}$ PS Agroteknologi, Fakultas Pertanian, Universitas Tribhuwana Tunggadewi, \\ Jl. Telaga Warna, Tlogomas, Malang, 65144; No Telp./Fax. 0341-565500/0341-565522 \\ * Corresponding Author: reza.prakoso@unitri.ac.id
}

\begin{abstract}
[CORRELATION AND PATH ANALYSES FOR DETERMINING THE SELECTION CRITERIA OF HIGH YIELDING SWEET POTATO (Ipomoea batatas (L.) Lam.)]. Sweet potatoes can be used as an alternative source of healthy carbohydrates. The productivity of sweet potato is relatively low, which was 13,51 tons/ha. To breed the potato plants one of the solutions to develop superior varieties. The success of plant breeding is determined by the success of the selection activity, one of which is determined by the selection characters used. Correlation and path analysis are used to study the closeness of the quantitative variables as the basis for a more efficient selection program. The purpose of the research was to determine the selection character of sweet potato and to study the correlation pattern between the observed characters based on the correlation coefficient value along with the direct and indirect effect. The research was carried out on dry land with Inceptisol soil type, at an altitude of $350 \mathrm{~m}$ above the sea level and arrange a randomized block design with three replications. The material used thirteen sweet potato genotypes. The results of the correlation analysis showed that the tuber yield had a very strong and positive correlation to the number of plants $(\mathrm{r}=0.706)$, the fresh weight of tuber $(\mathrm{r}=0.816)$, and dry weight of tuber $(\mathrm{r}=$ $0.898)$, while the tuber number had a moderate positive correlation. $(\mathrm{r}=0.605)$. Several variables also showed a negative relationship, including stover fresh weight, \% of tuber dry weight, dry weight of stover, and dry weight of biomass. Based on the correlation and path analysis, the variable of tuber dry weight can be used as an effective and efficient selection character in order to produce the high yield of sweet potatoes.
\end{abstract}

Keyword: correlation analysis, path analysis, selection, sweet potatoes

\begin{abstract}
ABSTRAK
Ubi jalar dapat digunakan sebagai salah satu alternatf sumber karbohidrat yang sehat. Produktivitas ubi jalar di relatif rendah yaitu sebesar 13,51 ton/ha. Kegiatan pemuliaan tanaman merupakan salah satu solusi untuk menghasilkan varietas unggul. Keberhasilan pemuliaan tanaman ditentukan oleh keberhasilan kegiatan seleksi salah satunya ditentukan dari karakter seleksi yang digunakan. Analisis korelasi dan analisis jalur digunakan untuk mempelajari hubungan keeratan antara variabel kuantitatif sebagai dasar program seleksi yang lebih efisien. Tujuan penelitian ini adalah untuk menentukan karakter seleksi ubi jalar dan mengetahui pola hubungan antara karakter pengamatan berdasarkan nilai koefisien korelasi serta pengaruh langsung dan tidak langsung. Pelaksanaan penelitian dilakukan pada lahan kering dengan jenis tanah Inceptisol di ketinggian $350 \mathrm{~m}$ dpl menggunakan Rancangan Acak Kelompok dengan tiga ulangan. Materi yang digunakan dalam penelitian tiga belas genotipe ubi jalar. Hasil analisis korelasi menunjukkan bahwa hasil umbi berkorelasi positif dan sangat kuat terhadap variabel jumlah tanaman $(\mathrm{r}=0,706)$, bobot segar umbi $(r=0,816)$, dan BK umbi $(r=0,898)$, sedangkan variabel jumlah umbi mempunyai korelasi positif yang sedang $(r=0,605)$. Beberapa variabel juga menunjukkan korelasi negatif meliputi bobot segar brangkasan, $\%$ BK umbi, BK brangkasan, dan BK biomassa. Berdasarkan analisis korelasi dan jalur variabel BK umbi dapat digunakan sebagai kriteria seleksi yang efektif dan efisien dalam menghasilkan ubi jalar berdaya hasil tinggi.
\end{abstract}

Kata kunci: analisis korelasi, analisis jalur, seleksi, ubi jalar 


\section{PENDAHULUAN}

Beras di Indonesia masih mendominasi sebagai sumber utama karbohidrat. Karbohidrat yang terkandung di dalam beras tidak baik untuk dikonsumsi dalam jumlah banyak, hal ini disebabkan kandungan glukosa yang tinggi. Glukosa dalam jumlah tinggi akan menyebabkan sulit untuk diserap oleh selsel dalam tubuh sehingga menyebabkan berbagai masalah kesehatan (Oba et al., 2010). Indonesia merupakan negara agraris dengan potensi sumber daya alam yang melimpah, memberikan kesempatan besar bagi Indonesia untuk memperoleh alternatif sumber karbohidrat.

Karbohidrat pada ubi jalar terdiri dari dari pati (53\%) dan gula sederhana seperti glukose, fruktose, sukrose, dan maltose (32\%) (Adda, 2015). Gula yang terkandung dalam ubi jalar berupa gula sederhana sehingga baik untuk dikonsumsi dalam jumlah banyak. Kadar pati pada tepung ubijalar berkisar antara 50-80\% (Zhu et al., 2011). Kadar pati yang tinggi pada ubijalar sangat diperlukan bagi kebutuhan industri pangan maupun bio-fuel (Mussoline \& Wilkie 2015; Wang et al., 2016). Klon-klon ubijalar yang mengandung kadar pati tinggi biasanya ditemukan pada klon-klon yang memiliki persen bahan kering umbi yang tinggi (Tian et al., 2018). Ubi jalar selain mempunyai kandungan karbohidrat yang cukup tinggi juga mempunyai kandungan berupa serat dan betakaroten, vitamin A (Giuliano, 2017; van Jaarsveld et al. 2006).

Pertumbuhan produktivitas ubi jalar di Indonesia mempunyai pola berbanding terbalik degan luas areal panen, hal ini berarti peningkatan luas panen tidak dapat diimbangi oleh peningkatan produktivitas tanaman. Laju peningkatan produktivitas tanaman ubi jalar di Indonesia mengalami peningkatan relatif rendah yaitu hanya sebesar $2,81 \%$. Produktivitas ubi jalar di Indonesia saat ini hanya sebesar 13,51 ton/ha dan lebih rendah dibandingkan negara lainnya seperti China, China daratan dan Nigeria yang mempunyai produktvitas antara 20,19-21,16 ton/ha (Suryani 2016). Negara penghasil ubi jalar terbesar di dunia sejak tahun 2010 yaitu negara Reunion (negara bagian Perancis) mempunyai produktivitas ubi jalar sebesar 32,27 ton/ha (Suryani, 2016). Edyson et al. (2019) menyatakan bahwa potensi hasil umbi hanya berkisar 8-23 ton dan brangkasan segar sebesar 5-24 ton pada umur panen 3,5 bulan setelah tanam. Faktor yang menjadi pembatas ketidaktercapaian hasil umbi dan brangkasan diakibatkan antara lain C-organik, $\mathrm{N}$ -total dan P-tersedia yang sangat rendah.

Ubi jalar di Indonesia selain mempunyai produktivitas yang relatif rendah juga mempunyai kualitas umbi yang kurang baik, hal ini dapat diketahui dari kandungan bahan kering. Kandungan bahan kering merupakan variabel penting dalam penentuan kualitas produksi ubi jalar, karena dapat dijadikan penanda untuk rasa legit atau punel ketika ubijalar direbus atau dibakar dan merupakan properti yang paling disukai oleh konsumen (Kathabwalika et al., 2013). Kadar bahan kering ubi jalar yang ada saat ini pada umumnya berkisar antara $20-30 \%$ pada umbi segar (Oliveira et al., 2017). Bahan kering ubi jalar termasuk kriteria tinggi jika mempunyai nilai bahan kering $\geq 31 \%$.

Saat ini, kon-klon ubijalar dengan kadar pati/ bahan kering tinggi masih terbatas. Varietas ubijalar berdaging umbi orange yang telah dilepas di Indonesia baru ada tiga, yakni Beta 1, Beta 2 dan Beta 3. Varietas Beta 1 dan Beta 2 masing-masing mempunyai kadar bahan kering $25.3 \%$ dan $23.8 \%$ (ILETRI, 2016), sedangkan Beta 3 mempunyai kadar bahan kering umbi sebesar 32.5\% (Jamil et al., 2016).

Rendahnya produktivitas dan kualitas ubi jalar di Indonesia salah satunya disebabkan terbatasnya varietas unggul yang tersedia. Kegiatan pemuliaan tanaman untuk menghasilkan varietas unggul merupakan salah satu solusi untuk meningkatkan produktivitas dan kualitas tanaman. Khayatnezhad et al. (2011) menyatakan bahwa tujuan terpenting dari program pemuliaan tanaman adalah untuk mendapatkan hasil tinggi dan kualitas umbi yang baik. Pemuliaan tanaman merupakan cara untuk memperoleh varietas unggul (O'Neill et al., 2004). Keberhasilan kegiatan pemuliaan ditentukan oleh keberhasilan kegiatan seleksi salah satunya ditentukan dari karakter seleksi yang digunakan. Analisis korelasi dan analisis jalur merupakan komponen penting dalam penentuan kriteria seleksi. Koefisien korelasi dapat digunakan untuk menentukan derajat keeratan hubungan antara hasil dan karakter lain. Analisis korelasi dapat digunakan untuk mengetahui hubungan keeratan antarkarakter penting tanaman (Mohanty et al. 2016).

Nilai koefisien korelasi belum dapat menunjukkan hubungan pengaruh langsung dan tidak langsung, serta belum dapat menentukan karakter yang paling berpengaruh sehingga untuk mengatasi kekurangan tersebut dilakukan dengan analisis jalur (Path analysis). Analisis jalur digunakan untuk mengetahui kontribusi dari masing-masing karakter terhadap hasil meliputi komponen pengaruh langsung dan pengaruh tidak langsung, sehingga diperoleh hubungan kausal yang dibangun dalam diagram dengan alur terpisah diantara karakter pengamatan (Toebe \& Filho, 2013; Kozak \& Azevedo, 2014). Analisis korelasi dan analisis jalur mempunyai manfaaat untuk mempelajari hubungan keeratan antara variabel kuantitatif dan digunakan sebagai dasar program seleksi yang lebih efisien (Nasution, 2010). Penelitian ini bertujuan untuk menentukan karakter seleksi ubi jalar yang mempunyai korelasi dengan hasil dan mengetahui pola hubungan antara karakter pengamatan berdasarkan nilai koefisien korelasi serta pengaruh langsung dan tidak langsung. 


\section{METODE PENELITIAN}

\section{Lokasi penelitian}

Penelitian dilaksanakan di Lahan Percobaan Universitas Brawijaya yang terletak di Desa, Jatikerto, Kecamatan Kromengan, Kabupaten Malang. Lokasi penelitian berada pada ketinggian $350 \mathrm{~m}$ di atas permu kaan laut. Jenis tanah pada lokasi penelitian yaitu Inseptisol.

\section{Bahan penelitian}

Penelitian ini menggunakan 13 genotipe ubi jalar yang meliputi Cangkuang-OP-22, Beta 2-9-12,

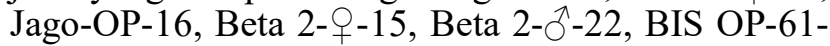
-36, Jago-OP-24, D67- - -23, Jago-OP-2, Jago-OP28 , Beta 1, Beta 2, dan Kuningan Merah.

\section{Rancangan Percobaan}

Rancangan percobaan yang digunakan dalam penelitian ini adalah Rancangan Acak Kelompok (RAK) dengan tiga ulangan. Unit percobaan terdiri atas barisan tunggal berukuran $3 \mathrm{~m} \times 0,6 \mathrm{~m}$ yang masing-masing ditanami stek ubi jalar dengan jarak tanam $25 \mathrm{~cm}$ dalam baris, sehingga terdapat 12 stek tiap plot baris. Budidaya ubijalar yang diterapkan dalam penelitian ini, meliputi dosis pupuk, frekuensi pemberian pupuk, turun gulud, naik gulud dan penyiangan bersamaan dengan proses turun gulud dan naik gulud. Dosis yang diberikan terdiri atas $300 \mathrm{~kg}$ Ponska/ha ditambah 100 $\mathrm{kg} \mathrm{KCl} / \mathrm{ha}$, diberikan dua kali, pertama pada umur 7 hari setelah tanam (hst) sebanyak 1/3 bagian dan sisanya diberikan pada umur 45 hst. Tanaman dipelihara dan dipanen pada umur 4 bulan setelah tanam.

\section{Variabel yan diamati dan Analisis Data}

Variabel yang diamati terdiri dari 10 variabel meliputi: jumlah tanaman, jumlah umbi, bobot segar umbi (kg), bobot segar brangkasan ( $\mathrm{kg}), \%$ BK umbi, $\%$ BK brangkasan, BK umbi $(\mathrm{kg})$, BK brangkasan $(\mathrm{kg})$, BK biomass $(\mathrm{kg})$, dan indeks panen (\%). Data yang diperoleh dianalisis korelasi dan analisis jalur dengan menggunakan aplikasi MINITAB. Koefisien korelasi merupakan nilai yang diperoleh dari hasil analisis korelasi. Koefisien korelasi dapat bernilai positif atau negatif yang berkisar antara -1 sampai dengan +1 . Nilai koefisien korelasi 0 menunjukkan tidak adanya korelasi; $0,001-0,20$ korelasi sangat lemah; $0,21-0,40$ korelasi lemah; $0,41-0,70$ korelasi sedang; 0,71 - 0,99 korelasi kuat; 1 korelasi sempurna.

\section{HASIL DAN PEMBAHASAN}

\section{Analisis korelasi}

Tiga belas genotipe yang dianalisis mempunyai keragaman genetik dan keragaman fenotipe yang luas terutama pada parameter jumlah umbi, bobot kering umbi, bobot kering brangkasan dan kadar betakaroten (Lestari \& Julianto 2020). Tingginya nilai keragaman genetik dan keragaman fenotipe menjadikan kegiatan seleksi dalam proses pemuliaan tanaman untuk menghasikan varietas unggul akan berjalan lebih efektif dan efisien. Tingkat hubungan keeratan antara variabel pengamatan dengan variabel pengamatan yang lainnya dapat diketahui berdasarkan hasil analisis korelasi, sehingga melalui analisis tersebut dapat diketahui variabel yang saling berkorelasi secara nyata. Kegiatan seleksi akan berjalan lebih efektif jika didukung dengan adanya informasi terkait hubungan korelasi antar variabel pengamatan dengan komponen hasil. Menurut Rohaeni \& Permadi (2012) menyatakan bahwa seleksi tidak langsung terhadap karakter utama dapat didasarkan dari nilai korelasi antar karakter.

Berdasarkan hasil analisis korelasi untuk memperoleh ubi jalar berdaya hasil tinggi diperoleh bahwa variabel pengamatan yang dapat digunakan sebagai kriteria seleksi dikarenakan mempunyai hubungan korelasi positif dan sangat kuat meliputi: jumlah tanaman $(r=$ 0,706), bobot segar umbi $(r=0,816)$, dan BK umbi ( $r$ $=0,898$ ), sedangkan variabel jumlah umbi mempunyai hubungan korelasi positif yang sedang $(\mathrm{r}=0,605)$. Hal ini sesuai dengan hasil penelitian dari Egbe et al. (2012) dan Mekonnen et al. (2015) bahwa jumlah umbi dan indeks panen (Gunjan 2012; Tirkey et al., 2011) nyata berkorelasi positif dengan hasil umbi. Hasil penelitian Afuape et al., (2015) dan Demelie \& Aragaw (2016) bahwa variabel bobot umbi dan indeks panen (Gunjan 2012) berkorelasi positif dan kuat terhadap hasil umbi. Nilai korelasi yang tinggi menunjukkan ada nya hubungan yang sangat kuat diantara variabel pengamatan, sehingga dalam melakukan seleksi dapat diterapkan seleksi secara tidak langsung untuk memperbaiki variabel tersebut.

Beberapa variabel juga menunjukkan hubungan yang berkorelasi negatif tetapi tidak nyata meliputi: bobot segar brangkasan $(\mathrm{r}=-0,116), \%$ BK umbi $(\mathrm{r}=$ $-0,101)$, BK brangkasan $(r=-0,353)$, dan BK biomassa $(r$ $=-0,314)$ (Tabel 1). Variabel yang menunjukkan korelasi positif dan nyata terhadap variabel BK umbi meliputi: jumlah tanaman $(r=0,763)$, jumlah umbi $(0,794)$, dan bobot segar umbi $(r=0,926)$, sedangkan variabel jumlah tanaman $(r=0,805)$ dan jumlah umbi $(r=0,850)$ menunjukkan korelasi positif dan nyata terhadap variabel bobot segar umbi. 
JULIANTO et al.

Tabel 1. Nilai koefisien korelasi antar variabel pada tanaman ubi jalar

\begin{tabular}{ccccccccccc}
\hline Karakter Agronomi & $\boldsymbol{X}_{\boldsymbol{1}}$ & $\boldsymbol{X}_{\boldsymbol{2}}$ & $\boldsymbol{X}_{\mathbf{3}}$ & $\boldsymbol{X}_{\mathbf{4}}$ & $\boldsymbol{X}_{\mathbf{5}}$ & $\boldsymbol{X}_{\boldsymbol{6}}$ & $\boldsymbol{X}_{\boldsymbol{7}}$ & $\boldsymbol{X}_{\boldsymbol{8}}$ & $\boldsymbol{X}_{\boldsymbol{9}}$ \\
\hline$X_{1}$ & $r$ & 1 & & & & & & & & \\
$\mathrm{X}_{2}$ & $r$ & $0,840^{* *}$ & 1 & & & & & & & \\
$\mathrm{X}_{3}$ & $r$ & $0,805^{* *}$ & $0,850^{* *}$ & 1 & & & & & & \\
$\mathrm{X}_{4}$ & $r$ & $-0,149$ & $-0,429$ & $-0,25$ & 1 & & & & & \\
$\mathrm{X}_{5}$ & $r$ & $-0,433$ & $-0,453$ & $-0,509$ & $-0,107$ & 1 & & & & \\
$\mathrm{X}_{6}$ & $r$ & 0,228 & 0,46 & 0,301 & $-0,409$ & $-0,086$ & 1 & & & \\
$\mathrm{X}_{7}$ & $r$ & $0,763^{* *}$ & $0,794^{* *}$ & $0,926^{* *}$ & $-0,368$ & $-0,163$ & 0,324 & 1 & & \\
$\mathrm{X}_{8}$ & $r$ & 0,087 & $-0,029$ & $-0,081$ & 0,265 & $-0,314$ & $-0,047$ & $-0,185$ & 1 & \\
$\mathrm{X}_{9}$ & $r$ & 0,123 & 0,007 & $-0,039$ & 0,25 & $-0,324$ & $-0,032$ & $-0,141$ & $0,999 * *$ & 1 \\
$\mathrm{X}_{10}$ & $r$ & $0,706^{* *}$ & $0,605^{*}$ & $0,816^{* *}$ & $-0,116$ & $-0,101$ & 0,182 & $0,898^{* *}$ & $-0,353$ & $-0,314$ \\
\hline
\end{tabular}

Keterangan : X1 : Jumlah tanaman; X2 : Jumlah umbi; X3 : Bobot segar umbi (kg/plot); X4 : Bobot segar Brangkasan (kg/ plot); X5 : \% BK umbi; X6 : \% BK Brangkasan; X7 : BK Umbi (kg/plot); X8 : BK Brangkasan (kg/plot); X9 : BK Biomassa $(\mathrm{kg} / \mathrm{plot}) ; \mathrm{X} 10$ : Indeks Panen $(\%), *=$ nyata, $* *=$ sangat nyata, $\mathrm{r}=$ koefisien korelasi.

Hubungan yang kuat dapat ditunjukkan dari nilai korelasi yang nyata, bukan disebabkan karena ada peluang tetapi benar-benar diakibatkan adanya hubungan antara dua variabel tersebut (Siregar, 2013).

Variabel yang dapat digunakan sebagai kriteria seleksi untuk memperoleh ubi jalar dengan hasil tinggi antara lain: jumlah tanaman, jumlah umbi, bobot segar umbi, dan BK umbi. Nilai korelasi yang relatif tinggi belum menggambarkan hubungan sebab akibat dan hanya menunjukkan keeratan hubungan antar sifat. Hubungan sebab akibat antara variabel dapat diketahui berdasarkan hasil analisis jalur dan dapat digunakan untuk membedakan pengaruh langsung dan tidak langsung ( $\mathrm{Li}, 1956)$. Penurunan produksi umbi akibat meningkatnya nilai berangkasan. Adanya kompetisi dalam perebutan unsur hara antara bagian atas tanaman dan bagian bawah tanaman (umbi) (Hapsai et al., 2011). Hasil yang sama ditunjukkan oleh Putra \& Permandi (2011) bahwa bobot umbi mengalami penurunan disebabkan jumlah berang-kasan yang meningkat.

Produktivitas ubi jalar selain dipengaruhi oleh faktor genetik juga dipengaruhi olehh faktor lingkungan terutamanya faktor curah hujan dan kesuburan tanah. Menurut Sitorus et al. (2011) dan Motsa et al. (2015) bahwa faktor pembatas utama tercapainya potensi hasil tanaman diakibatkan oleh kondisi kimia tanah, fisik lahan, dan lahan terdegrasi. Pertumbuhan dan komponen hasil ubi jalar sangat dipengaruhi oleh kelebihan dan keterbatasan volume curah hujan (Lestari \& Hapsari, 2015 ; Saitama et al., 2017). Tipe pertumbuhan ubi jalar di lahan kering dapat berubah dari ubi jalar tipe forage ke tipe dual-purpose dan sebaliknya dari tipe dual-purpose dapat berubah menjadi tipe forage ketika besarnya curah hujan berubah (Lestari \& Hapsari 2015). Demikian pula penelitian Biswal et al. (2017) menunjukkan bahwa ubi jalar sangat sensitif terhadap terjadinya kelebihan dan kekurangan air, terutama pada pembentukan dan perkembangan ukuran umbi. Penelitian Indawan et al. (2018) juga memberi gambaran serupa terhadap komponen-komponen hasil ubi jalar ketika terjadi perubahan sifat-sifat kimia tanah akibat pemberian bahan pembenah tanah (biochar). Selain biochar, bahan pembenah tanah yang lain yang dapat memperbaiki sifat-sifat tanah antara lain adalah pupuk kotoran ayam, dapat meningkatkan serapan hara tanah, khususnya adalah unsur N, P, dan K (Maftu'ah et al., 2013). Hasil penelitian menggunakan biochar dapat memperbaiki kesuburan tanah (Ding et al., 2016). Hasil penelitian Uwah et al. (2013) menunjukkan meskipun ubi jalar sangat toleran terhadap tanah yang miskin hara, namun pemupukan kalium sangat diperlukan untuk meningkatkan hasil secara optimum pada ubi jalar.

\section{Analisis jalur}

Analisis korelasi menurut Roy (2000) digunakan untuk menggambarkan tingkat keeratan antara variabel variabel pengamatan satu dengan yang lainnya, tetapi analisis korelasi tidak dapat menjelaskan tentang hubungan sebab akibar dari tingkat keeratan antara variabel pengamatan tersebut. Hasil analisis jalur mampu menjabarkan besarnya pengaruh langsung dan tidak langsung suatu variabel terhadap variabel yang lain. Analisis jalur dalam penelitian dilakukan dengan tujuan untuk mengetahui besarnya pengaruh langsung dan tidak langsung variabel jumlah tanaman, jumlah umbi, bobot segar umbi, dan bobot kering umbi terhadap indeks panen, sedangkan variabel lain seperti bobot segar umbi, bobot segar brangkasan, \% BK umbi, \% BK brangkasan, BK brangkasan, dan BK biomassa tidak dilakukan analisis jalur, hal ini dikarenakan variabel tersebut tidak menunjukkan adanya korelasi nyata dengan indeks panen. 
Tabel 2. Pengaruh langsung dan tidak langsung beberapa karakter terhadap variabel indeks panen

\begin{tabular}{|c|c|c|c|c|c|c|c|}
\hline \multirow{2}{*}{ Karakter Agronomi } & \multirow{2}{*}{ Pengaruh Langsung } & \multicolumn{4}{|c|}{ Pengaruh Tidak Langsung } & \multirow{2}{*}{$\begin{array}{c}\text { Total } \\
\text { Pengaruh } \\
\text { Tidak } \\
\text { Langsung }\end{array}$} & \multirow{2}{*}{$\begin{array}{c}\text { Total } \\
\text { Pengaruh }\end{array}$} \\
\hline & & $\mathrm{X}_{1}$ & $X_{2}$ & $X_{3}$ & $\mathrm{X}_{7}$ & & \\
\hline $\mathrm{X}_{1}$ & 0,104 & & 0,142 & $-0,023$ & $-0,242$ & $-0,124$ & $-0,02$ \\
\hline $\mathrm{X}_{2}$ & 0,275 & 0,142 & & 0,04 & $-0,41$ & $-0,228$ & 0,047 \\
\hline $\mathrm{X}_{3}$ & 0,008 & $-0,023$ & 0,04 & & 0,082 & 0,099 & 0,107 \\
\hline $\mathrm{X}_{7}$ & 0,97 & $-0,242$ & $-0,41$ & 0,082 & & $-0,57$ & 0,4 \\
\hline \multicolumn{7}{|c|}{ Total pengaruh } & 0,534 \\
\hline
\end{tabular}

Keterangan $=\mathrm{X}_{1}$ : Jumlah tanaman; $\mathrm{X}_{2}$ : Jumlah umbi; $\mathrm{X}_{3}$ : Bobot segar umbi (kg/plot); $\mathrm{X}_{7}$ : BK Umbi (kg/plot).

Variabel yang mempunyai pengaruh langsung tertinggi terhadap indeks panen yaitu variabel BK umbi dengan nilai koefisien jalur sebesar 0,970, sedangkan variabel lain seperti jumlah tanaman, jumlah umbi dan bobot segar brangkasan mempunyai pengaruh langsung lebih kecil dibandingkan dengan BK umbi yaitu dengan nilai koefisien jalurnya sebesar 0,104 ; 0,275; dan 0,008 (Tabel 2). Variabel pengamatan BK umbi menjadi komponen penting terhadap indeks panen, selain itu BK umbi juga dapat digunakan sebagai krtiteria seleksi dalam menghasilkan ubi jalar dengan nilai indeks panen tinggi. Variabel BK umbi selain mempunyai pengaruh langsung tertinggi juga mempunyai pengaruh total tertinggi. Variabel jumlah tanaman mempunyai pengaruh tidak langsung tertinggi terhadap indeks panen melalui jumlah umbi dengan nilai koefisien jalurnya sebesar 0,142, sehingga jika seleksi dilakukan berdasarkan variabel jumlah tanaman maka harus mempertimbangan jumlah umbi.

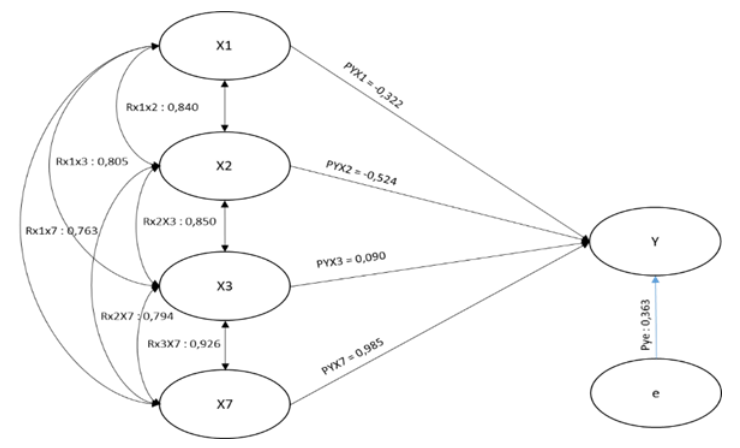

Gambar 1. Diagram jalur karakter agronomi dan indek panen tanaman ubi jalar

Koefisien residu berdasarkan diagram jalur (Gambar 1) yaitu sebesar 0,363. Dengan demikian, besarnya nilai indeks panen yang terkait dengan 4 variabel meliputi jumlah tanaman, jumlah umbi, bobot segar umbi, dan BK umbi yang diamati adalah 1-R2 $=86,8 \%$. Nilai tersebut menunjukkan bahwa variabel pengamatan BK umbi memberikan pengaruh langsung yang terpenting terhadap nilai indeks panen. Hal ini sesuai dengan beberapa hasil penelitian yang menunjukkan bahwa karakter bobot umbi akan memberikan pengaruh langsung terpenting terhadap hasil (Gedamu et al., 2010; Madawal et al., 2015; Tsegaye et al., 2006; Workalemahu \& Mohammed, 2016). Selain itu juga sesuai dengan hasil penelitian Hakim (2012) bahwa bobot umbi per plot memberikan pengaruh utama terhadap hasil umbi ubi jalar, meskipun terdapat faktor lain yang tidak terukur ikut dalam mempengaruhi hasil umbi ubi jalar.

Nilai koefisien korelasi tertinggi yang berpengaruh terhadap hasil ditunjukkan pada variabel BK umbi $\left(\mathrm{r}=0,898^{* *}\right)$, ini sesuai dengan hasil path analyses yang menunjukkan bahwa variabel BK umbi mempunyai pengaruh langsung dan total pengaruh terbesar terhadap hasil umbi. Hasil analisis korelasi diperkuat oleh hasil path analysis sehingga informasi tersebut dapat digunakan sebagai penentuan kriteria seleksi yang efektif dan efisien untuk menghasilkan ubi jalar berdaya hasil tinggi. Nilai residu dari hasil analisis jalur merupakan nilai total pengaruh langsung sisa yang belum terhitungkan pada variabel yang belum diamati. Nilai residu yang semakin kecil atau mendekati nol menunjukkan semakin efektif hasil analisis jalur untuk menjelaskan sebab dan akibat dari nilai korelasi (Rohaeni \& Permadi 2012). Berdasarkan hasil analisis jalur nilai residu hasil penelitian ini sebesar Pye $=0,363$ atau $36,3 \%$, sehingga nilai tersebut menunjukkan semakin efektif suatu karakter digunakan untuk seleksi terhadap variabel hasil.

\section{KESIMPULAN}

Hasil analisis korelasi menunjukkan bahwa hasil umbi berkorelasi positif dan sangat kuat terhadap variabel jumlah tanaman $(r=0,706)$, bobot segar um- 
bi $(\mathrm{r}=0,816)$, dan BK umbi $(\mathrm{r}=0,898)$, sedangkan variabel jumlah umbi mempunyai korelasi positif yang sedang $(r=0,605)$. Beberapa variabel juga menunjukkan korelasi negatif meliputi bobot segar brangkasan, \% BK umbi, BK brangkasan, dan BK biomassa. Berdasarkan analisis korelasi dan analisi jalur variabel BK umbi dapat digunakan sebagai variabel seleksi yang efektif dan efisien dalam menghasilkan ubi jalar berdaya hasil tinggi.

\section{SANWACANA}

Ucapan terima kasih disampaikan kepada : Kemenristek-Dikti yang telah membiayai pelaksanaan penelitian ini melalui Program Hibah Penelitian Terapan Unggulan Perguruan Tinggi (PTUPT) Tahun 20182020 dan Lembaga Penelitian dan Pengabdian Masyarakat (LPPM) Universitas Tribhuwana Tunggadewi yang telah memfasilitasi kegiatan ini.

\section{DAFTAR PUSTAKA}

Adda, B. (2015). Sweet Potatoes 101: Nutrition Facts and Health Benefits.

Afuape, S., Okocha, P.I. \& Njoku, D. (2015) Multivariate assessment of the agromorphological variability and yield components among sweet potato (Ipomoea batatas (L.) Lam ) landraces. African Journal of Plant Sciences. 5, 123-132.

Biswal, S., Nedunchezhiyan, Mohapatra, P.K. \& Vigyan, K. (2017) Effect of irrigation schedule and fertilizer levels on growth and yield of sweet potato (Ipomoea batatas L.). Journal of Root Crops. 43(1), 44-51.

Demelie, M. \& Aragaw, A. (2016) Genetic variability of sweet potato on yield and yield related traits at werer Agricultural Research Center, Ethiopia. Electronic Journal of Plant Breeding. 7, 362370. DOI: https://10.5958/0975-928X.2016. 00044.2.

Ding, Y., Y. Liu, S. Liu, Z. Li, X. Tan, X. Huang, G. Zeng, L. Zhou, \& B. Zheng. (2016) Biochar to improve soil fertility. A review. Agronomy for Sustainable Development. Dev. 36. DOI: https://10.1007/s13593-016-0372-z.

Edyson, I., Lestari, S.U. \& Thiasari, N. (2019) Pemberian biocar jengkok tembakau untuk meningkatkan hasil ubi jalar pada lahan kering sub-optimal. Jurnal Lahan Suboptimal, 8(1), 47-56. DOI: https://doi.org/10.33230/JLSO. 8.1.2019.284.

Egbe, O.M., Afuape, S.O. \& J. A. Idoko (2012) Performance of improved sweet potato (Ipomoea batatas L.) varieties in Makurdi, Southern Guinea Savanna of Nigeria. American Journal of Experimental Agriculture. 2(4), 573-586. DOI : https:// 10.9734/AJEA/2012/1347.
Gedamu, Y., Belay, G. \& Dechassa, N. (2010) Genotypic and phenotypic correlations of root yield and other traits of orange-fleshed sweet potatoes (Ipomoea batatas (L.) Lam.). Journal of the Drylands, 3, 208-213.

Giuliano, G. (2017) Provitamin A biofortification of crop plants: a gold rush with many miners. Current opinion in biotechnology.,44, 169-180.

Gunjan, J. (2012) Increasing Productivity of Sweet potato, Ipomoea batatas (L.) Lam through clonal selection of ideal genotypes from open pollinated seedling population. International Journal of Farm Sciences, 2(2), 17-27.

Hakim, L. (2012) Komponen hasil dan karakter morfologi penentu hasil kedelai. Jurnal Penelitian Pertanian Tanaman Pangan. 31, 173-179.

Hapsari, R.., Mejaya, I.M.J \& Sulistyo, A. (2011). Uji toleransi beberapa klon ubijalar terhadap kekeringan berdasarkan karakter agronomik tanaman. In: Prosiding Seminar Hasil Penelitian Tanaman Aneka Kacang dan Umbi. hal .685-694.

ILETRI (2016) Deskripsi Varietas Ubi Jalar 19772016. 36.

Indawan, E., Lestari, S.U. \& Thiasari, N. (2018) Sweet potato response to biochar application on sub-optimal dry land. Journal of Degraded and Mining Lands Management, 5(2), 11331139.

Van Jaarsveld, P.J., D.W. Marais, E. Harmse, P. Nestel, \& D.B. Rodriguez-Amaya. (2006) Retention of $\beta$-carotene in boiled, mashed orange-fleshed sweet potato. Journal of Food Composition and Analysis, 19(4), 321-329.

Jamil, A., Mejaya, M.J., Praptana, R.H., Subekti, N.A., Aqil, M.,Musaddad, A. \& Putri, F.(2016). Deskripsi Varietas Unggul Tanaman Pangan 2010-2016. 142.

Kathabwalika, D.M., E.H.C. Chilembwe, V.M. Mwale, D. Kambewa, \& J.P. Njoloma. (2013) Plant growth and yield stability of orange fleshed sweet potato (Ipomoea batatas) genotypes in three agro-ecological zones of Malawi. International Research Journal of Agricultural Science and Soil Science. 3(11), 383-392.

Khayatnezhad, M., R. Shahriari, R. Gholamin, S. Jamaati-E-Somarin \& Zabihi-E-Mahmoodabad, R. (2011). Correlation and path analysis between yield and yield components in potato (Solanum tuberosum L.).Middle-East Journal of Scientific Research, 7(1), 17-21.

Kozak, M. \& Azevedo, R. (2014) Sequential path analysis: What does "sequential" mean? Scientia Agricola, 71, 525-527.

Lestari, S.U. \& Hapsari, R.I. (2015) Dual-purpose assessment for sweetpotato. Agrivita. 37(2), 123-129. 
Lestari, S.U. \& Julianto, R.P.D. (2020) Analisis keragaman genetik dan kekerabatan genotipe ubi jalar berdasarkan karakter morfologi. Buletin Palawija. 18(2), 113-122.

Li, C.C. (1956) The concept of path coefficient and its impact on population genetics. Biometrics. 12(2), 190-210.

Madawal, S., Alloli, T., Madarakhandi, S. \& Ambresh (2015) Genotypic and phenotypic correlation of tuber yield and other trait of orange-fleshed sweetpotatoes (Ipomoea batatas (L). Lam). IJTA. 33(2), 283-287.

Maftu'ah, E., Maas, A., Syukur, A. \& Purwanto, B.H. (2013) Efektivitas amelioran pada lahan gambut terdegradasi untuk meningkatkan pertumbuhan dan serapan NPK tanaman jagung manis (Zea mays L. var. saccharata). Jurnal Agronomi Indonesia (Indonesian Journal of Agronomy). 41(1), 16-23.

Mekonnen, B., Tulu, S. \& Nego, J. (2015) Evaluation of orange fleshed sweet potato (Ipomoea batatas L.) varieties for yield and yield contributing parameters in the humid tropics of Southwestern Ethiopia. Journal of Plant Sciences, 10(5), 191 -199 .

Mohanty, P. (2016) Character association and path analysis in sweet potato (Ipomoea batatas (L.) Lam.) genotypes. Life Sciences. 5, 441-448.

Motsa, N., Modi, A. \& Mabhaudhi, T. (2015) Sweet potato response to low-input agriculture and varying environments of KwaZulu-Natal, South Africa: implications for food security strategies. Acta Agriculturae Scandinavica, Section B - Soil \& Plant Science, 65.

Mussoline, W.A. \& Wilkie, A.C. (2015) Anaerobic Digestion Potential of Coproducts Associated with Ethanol Production from Sweetpotato: A Review.IndustrialBiotechnology,11(2),113-126.

Nasution, M.A. (2010) Analisis korelasi dan sidik lintas antara karakter morfologi dan komponen buah tanaman nenas (Ananas comosus L. Merr.). Jurnal Crop Agro, 3(1), 1-9.

O’Neill, P., J. Shanahan, J.. Schepers \& Caldwell, B. (2004) Agronomic responses of corn hybrids from different eras to deficit and adequate levels of water and nitrogen. Agronomy Journal, 96.

Oba, S., Nagata, C., Nakamura, K., K. Fujii, T. Kawachi, Takatsuka, N. \& Shimizu, H. (2010) Dietary glycemic index, glycemic load, and intake of carbohydrate and rice in relation to risk of mortality from stroke and its subtypes in Japanese men and women. Metabolism: clinical and experimental, 59(11), 1574-1582. DOI: https://10. 1016/ j.metabol.2010.02.004.

Oliveira, A.M., Blank, A.F., Alves, R.P., Arrigoniblank, M.F. \& Maluf, W.R. (2017) Performanœ of sweet potato clones for bioethanol production in different cultivation periods. Horticultura Brasileira. 35(1), 57-62.

Putra, S. \& Permandi, K. (2011) Pengaruh pupuk kalium terhadap peningkatan hasil ubi jalar varietas narutokintoki di lahan sawah. Jurnal Agrin. 15(2), 133-142.

Rohaeni, W.R. \& Permadi, D.A.N.K. (2012) Analisis sidik lintas beberapa karakter komponen hasil terhadap daya hasil padi sawah pada aplikasi Agrisimba. Agrotrop: Journal on Agriculture Science, 2(2), 185-190.

Roy, D. (2000) Plant Breeding Analysis and Exploitation of Variation. Narosa Publishing House, New Delhi.

Saitama, A., Nugroho, A. \& Widaryanto, E. (2017) Yield response of ten varieties of sweet potato (Ipomoea batatas L.) cultivated on dryland in rainy season. Journal of Degraded and Mining Lands Management. 04(04), 919-926. DOI: https://10.15243/jdmlm.2017.044.919

Singh, R. \& Chaudary, B.D. (2010). Biometrical Methods in Quantitative Genetics Analysis. Kalyani Publishers, New Delhi.

Siregar, S. (2013) Statistik Parametrik untuk Penelitian Kuantitatif. Bumi Aksara, Jakarta.

Sitorus, S.., Susanto, B. \& Haridjaja, O. (2011) Kriteria dan klasifikasi tingkat degradasi lahan di lahan kering (Studi Kasus: Lahan Kering di Kabupaten Bogor). Jurnal Tanah dan Iklim. 34, 66-83.

Streiner, D.L. (2005) Finding our way: An introduction to path analysis. Canadian Journal of Psychiatry. 50(2), 115-122.

Suryani, R. (2016). Outlook Komoditas Pertanian Sub Sektor Tanaman Pangan. Pusat Data dan Sistem Informasi Pertanian Kementerian Pertanian 2016, Pusat Data dan Sistem Informasi Pertanian Kementerian Pertanian, Jakarta.

Tian, S.Q.T., Zhao, R.-Y. \& Zhao, J.L. (2018) Production of bioethanol from sweet potato tubers with different storage times. BioResources. 13(3), 4795-4806.

Tirkey, P.L., J. Singh, P.C.Chaurasia, \& D.A. Sarnaik. (2011) Character association and path coefficient studies in sweet potato (Ipomoea batatas (L.) Lam.) genotypes. Journal of Plant Development Sciences. 3(1 \& 2), 137-143.

Toebe, M. \& Cargnelutti Filho, A. (2013) Multicollinearity in path analysis of maize (Zea mays L.). Journal of Cereal Science. 57, 453-462. DOI: https// doi.org/10.1016/j.jcs.2013.01.014.

Tsegaye, E., Sastry, E.V.D. \& Dechassa, N. (2006) Correlation and Path Analysis in Sweet Potato and Their Implications for Clonal Selectin. Jurnal Agronomi Indonesia (Indonesian Journal of Agronomy). 5(3), 391-395. 


\section{JULIANTO et al.}

Uwah, D., Undie, U.L., John N.M. \& Ukoha, G.O. (2013) Growth and yield response of improved sweet potato (Ipomoea batatas (L.) Lam) varieties to different rates of potassium fertilizer in Calabar, Nigeria. Journal of Agricultural Science, 5(7), 61-69.

Wang, S., Nie, S.P. \& Zhu, F. (2016) Chemical constituents and health effects of sweet potato. Food Research International. 89.
Workalemahu, G. \& Mohammed, W. (2016) Correlation coefficients, path analysis and disease reaction between yield and yield components in Potato (Solanum tuberosum L.) genotypes in Bale, South Eastern Ethiopia. Plant Science Today. 3, 293.

Zhu, F., X. Yang, Y.Z. Cai, Bertoft, E. \& Corke, H. (2011) Physicochemical properties of sweet potato starch. Starch - Stärke. 63, 249-259. 